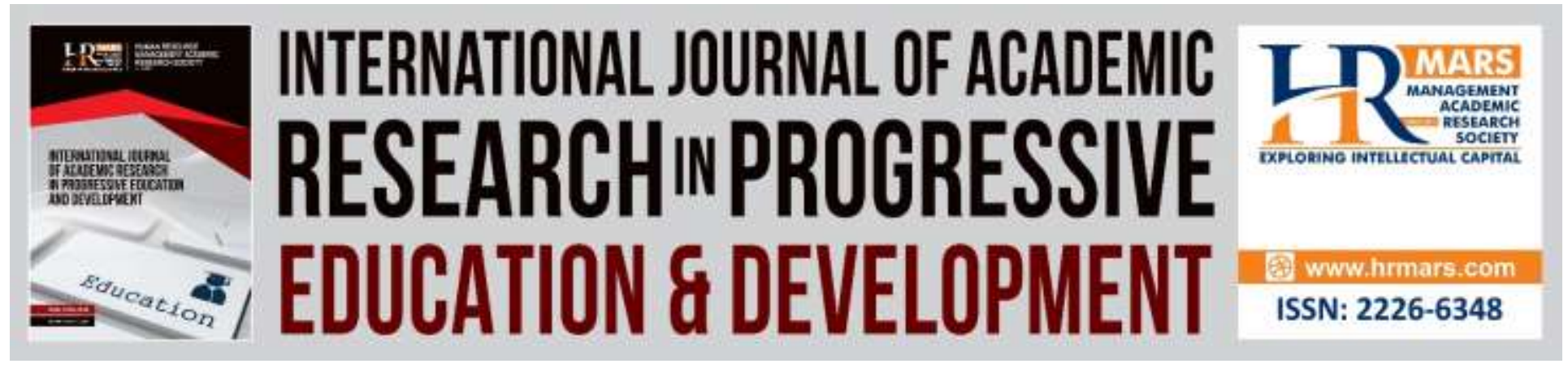

\title{
Applications Art Appreciation in Teaching and Learning in Primary School
}

Cherise Tan Sheau Ping, Che Aleha Ladin

To Link this Article: http://dx.doi.org/10.6007/IJARPED/v8-i4/6441 DOI: 10.6007/IJARPED/v8-i4/6441

Received: 02 August 2019, Revised: 19 August 2019, Accepted: 01 September 2019

Published Online: 11 September, 2019

In-Text Citation: (Ping \& Ladin, 2019)

To Cite this Article: Ping, C. T. S., \& Ladin, C. A. (2019). Applications Art Appreciation in Teaching and Learning in Primary School. International Journal of Academic Research in Progressive Education and Development, 8(4), 130-140.

Copyright: (c) 2019 The Author(s)

Published by Human Resource Management Academic Research Society (www.hrmars.com)

This article is published under the Creative Commons Attribution (CC BY 4.0) license. Anyone may reproduce, distribute, translate and create derivative works of this article (for both commercial and non-commercial purposes), subject to full attribution to the original publication and authors. The full terms of this license may be seen

at: http://creativecommons.org/licences/by/4.0/legalcode

Vol. 8(4) 2019, Pg. 130- 140

http://hrmars.com/index.php/pages/detail/IJARPED

JOURNAL HOMEPAGE

Full Terms \& Conditions of access and use can be found at http://hrmars.com/index.php/pages/detail/publication-ethics 


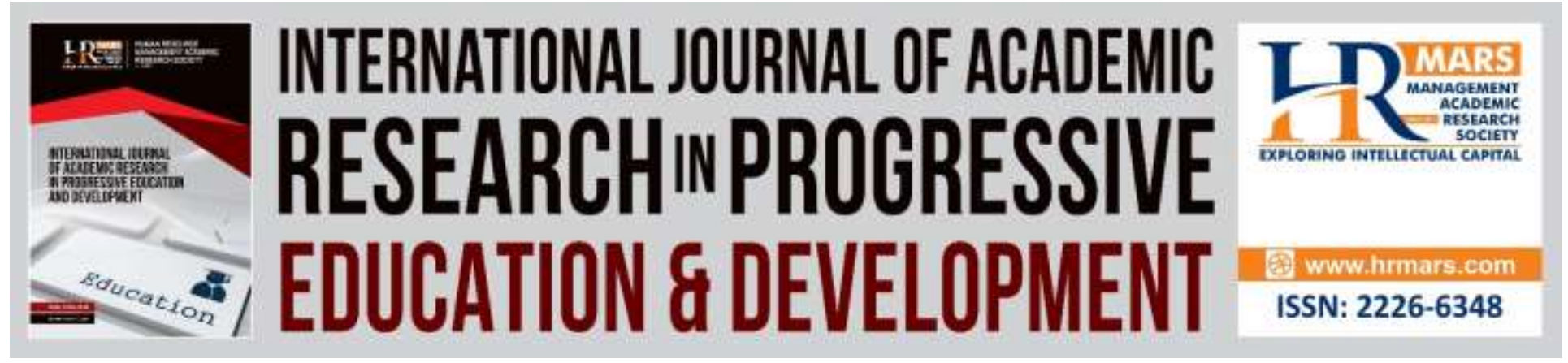

\title{
Applications Art Appreciation in Teaching and Learning in Primary School
}

\author{
Cherise Tan Sheau Ping, Che Aleha Ladin \\ University of Malaya, Malaysia
}

\begin{abstract}
Art appreciation is a part of the field of art criticism. Art appreciation involves the elements and principles of art. This study aims to identify the level of students' understanding and problems during the application of art appreciation sessions in teaching and learning in primary school. This study uses a qualitative approach in the form of a case study. Data analysis was collected using interview, observation and document analysis to observe pupils' behavior and understanding level. Two students from Year 6 and one visual art teacher were selected as the participants of the study. The data were analyzed descriptively. Participants of the study were selected on purposive sampling. The findings show that students' level of understanding the element of art is low. In addition, students are less fluent in Malay Language which made them unable to perform the session with a good art appreciation. The way of teaching is also not focused on aesthetic perceptions. This problem causes students to become less interested and less confident. Therefore, researchers suggested that teachers be given a comprehensive overview of how to carry out art appreciation sessions in school to ensure that their artwork can be appreciated by the students.
\end{abstract}

Keywords: Art Appreciation, Teaching and Learning, Art Educations, Primary School

\section{Introduction}

Art education is very important in life as it can be generating creativity, communication and intelligence (Maneen, 2016; Savva \& Trimis, 2005; Terreni, 2016). According to aspiration of the National Philosophy of Education (FPK) (Subramaniam, 2017; Tekiner, 2006) in Malaysia, the curriculum art education was created to produce visual literacy skills generations. Therefore, the school environment should impact the awareness, understanding, appreciation and appreciation of visual art which can be inspired through murals, banners and statues. (Kementerian Pendidikan Malaysia, 2017).

The value of appreciation brings art appreciation more in line (Carroll, 2016) with how we determine the meaning of an event, person, behavior or object (Fagley, 2012; Khalid, Pahi, \& Ahmed, (2016). This is a necessary training in which engagement of the senses and touch (Ali, 1989; Hamid, 2004) to understand it. Art appreciation is part of the field of art criticism. There 
are two types which are formalistic art criticism and aesthetic appreciation. Formal art criticism is an intrinsic value that includes elements of art and design principles (Noaparast \& Noaparast, 2011). While aesthetic appreciation refers to the elements of experience namely tools and materials, expressions, designs and so on (Leder, Belke, Oeberst, \& Augustin, 2004; Meel-Jansen, 2006; Parsons, 2004). According to (Subramaniam, 2017; Madrid, Ahmed, \& Kumar, (2019) , art appreciation can ensure that students are engaged in expressing their own feelings and ideas and nurturing students to appreciate the artwork they have created. Elements of art and design principles are fundamental components for creating and criticizing a work of art.

\section{Statement of the Problem}

Art appreciation can be learned by students to widen their vision in art education (Law, 2010). This approach can build communication skills, build self-confidence (Ariffin, 2010) and train students to communicate (Novaković, 2015). The study of art education should emphasize the process of production by involving aspects of understanding, appreciation and appreciation of art (Ismail, 2015). The process of conducting art appreciation sessions needs to be refined and guided by classroom teachers. However, the teacher always more focused on producing artwork than art appreciation sessions in the classroom (Setiawan, 2007). Thus, neglecting art appreciation session in the classroom made those student lack of knowledge in art includes an understanding of the elements of art and design principles in creating art appreciation.

Understanding and mastering the elements of art and design principles are essential by the artist. Art teachers need to incorporate these elements into their teaching process. Although various methods and initiatives have been implemented to ensure that students master the language of visual arts in writing and listening, the study found that students still lack of the skills to appreciate of art (Ariffin, 2010; Ibrahim, 2007). According to Ariffin (2010), the study found that Chinese students were less interested in art (34.31\%) than Malays (49.23\%). This has been supported by Woon (2015), the study found that Chinese people viewed art as less important than other subjects. The perception of the importance of art among students causes the art learning sessions to become worse. The improper conducted by teachers and students made effects on art appreciation sessions in school. Thus, students couldn't have the chance to convey ideas and criticisms of art well.

\section{Research Questions}

This study focuses on two main research questions:

1. What problems did the students face when performing art appreciation sessions?

2. What is the level of student understanding of art appreciation sessions?

\section{Research Objectives}

a. Identify student problems during art appreciation sessions.

b. Identify student level of understanding during art appreciation sessions. 


\section{Literature Review}

Theory of Multiple Experiences is a theory of art appreciation presented by Edmund Burke Feldman. This theory designed for art educators learns how to teach art appreciation and art criticism. Feldman's method of criticism model has four steps to follow in order to understand a work of art, namely, description, analysis, interpretation and evaluation. However, the teacher's misunderstanding of the arts language elements clearly indicates that the teacher has neglected the implementation of art appreciation in the teaching and learning during the art sessions. Discipline-Based Art Education (DBAE) also has four domains of art which are art aesthetics, art criticism, art history and art products. The four domains of DBAE are essential in the implementation of art appreciation (Hedayat, Kahn, Honarvar, Bakar, \& Samsuddin, 2013). It also an interconnected and need to be utilized in the teaching of art education to ensure pupils can achieve a deep and meaningful appreciation of art.

There are many studies that look at the mastery and skills of students in art appreciation. Setiawan (2007) found that art appreciation sessions are rarely implemented by teachers and this results in students being less skilled at evaluating artwork. Her research also found that teachers lacked knowledge about elements of art and design principles to be applied in the teaching of art appreciation.

In addition, Law (2010) found that an interdisciplinary approach to art appreciation has become more diverse. This study relates the importance of art appreciation between art and other disciplines including aesthetics, anthropology, history, social studies, and even science. In this regard, the study also showed that students who value of artwork can develop critical and creative thinking skills. Art appreciation is crucial to developing students' intellectual, emotional and social art experiences and ultimately instills aesthetic values.

Teachers play an important role in ensuring the success of art appreciation sessions in the classroom. Pupils should be given the opportunity to evaluate and communicate verbally in the use of art language in order to create a community that values art. Chia (2011) found that teachers need to be careful about evaluating student processes when doing work, rather than simply evaluating at the end of products. In fact, when evaluating rubric sets need to be attached and based on the curriculum of constructivism. Applied art appreciation can enhance communication and writing skills in the classroom. In her research found that teachers are facilitators who guide the process of art appreciation sessions in teaching and learning in schools. Students are given the opportunity to freely express themselves. However, looking at the eastern perspective, Asian students are still inclined to give their views and needs to be addressed by the teacher step by step during the art appreciation session in order to improve their self-confidence.

Furthermore, Ariffin (2010) studied the factors that led to student interest in the implementation of appreciation sessions. The study also showed that the interest in art appreciation is related to internal factors and external factors. In this study, the cognitive theory and approach Discipline-Based Art Education (DBAE) has been introduced. Students who are passive in the classroom because of traditional teacher-centered pedagogy are still practiced. 
Vol. 8, No. 4, 2019, E-ISSN: 2226-6348 @ 2019 HRMARS

The findings show that $85 \%$ of students are still interested in conducting art appreciation sessions because they can appreciate different types of painting work and this is the way to improve their drawing skills, instrumentation, materials and colors through discussions with teachers.

\section{Methodology}

This study is a qualitative study in the form of a descriptive case study. Descriptive research aims to gather information and to describe phenomena that exist or occur. Descriptive studies focus more on what and how to get answers to the questions that have been asked. The researcher also studying, analyzing and summarizes the best possible problems that arise in the form of a qualitative approach.

\section{Samples}

The study was conducted by an art teacher and two twelve years old students at a primary school in Jinjang X. Selection of the samples of the study was made by purposive sampling. The purposive sampling technique was being used in this research. This sampling technique was also suggested by the art teacher who teaches the student. The samples of the selected study are among those who are committed, shameless and willing to provide the necessary information.

\section{Instruments}

The researcher used two types of methods to collect data which is observation and interview. Observation is a very important method of qualitative research. The purpose is to record and retrieve any data during the art appreciation process that is conducted in the classroom. During the observation, the researcher will record everything that happens in the observation record form marked with code 01 . Observations on teacher A will be code A01.

Interview methods were conducted for students as the researcher wanted to know the feelings, views and explain the students' understanding of art appreciation sessions. The method used by the researcher was a semi-structured interview which provided questions but the answers to the questions were open. In order to have the interview data captured more effectively, recording of the interviews is considered an appropriate choice. The interview with the teacher is to get more information about the process of applying the appreciation and the problems that the student is facing. The recording of the interview makes it easier for the researcher to focus on the interview content and the verbal prompts and thus enables the transcriptionist to generate a "verbatim transcript" of the interview. It is useful for the researcher studied in detail and linked with analysis notes. All the documents related to the interview will be marked with code 02 . The document review includes student work presented during the art appreciation sessions in the classroom.

\section{Method of Data Analysis}

The data analysis in this study was made qualitatively. The first step for the researcher is to copy the audio tape in the form of a transcript or to involve the verbatim data transcription process. Then, the researcher filters the data by providing an index or code. Once an index or code has been provided, the researcher needs to understand the data by examining what the 
subject of the study said. To facilitate the analysis of each transcript line, the researcher will provide code and theme as guidance to the study.

The qualitative researcher collected performances by the observation. Observation methods can be helpful for teachers and students during teaching and learning sessions. During the observation, observation and record field notes as well as to involve themselves as a sample marked with code 01 . The researcher recorded the activities that took place during the art appreciation session.

\section{Finding, Results and Discussions}

\section{Students' Problems in Art Appreciation Session}

No Knowledge of the element and principles of art

Based on the data from interviews and observations, this study has found that students face problems during art appreciation session. They do not know or do not thoroughly understand the languages of elements and design principles taught by the teacher. The findings from interviews have found that some students try to guess the element of art when they are questioned by the teacher. Some even refuse to comment on what they observed. According to teacher A,

"Some students refuse to comment. They are very quiet and do not know how to comment. Students also cannot differentiate or confuse the elements of art during art appreciation session in class. Sometimes there are time constraints in executing art appreciation session." (T2A2)

"When the teacher queries on the elements and principles of art based on pictures shown, only a few pupils try to answer the question by guessing." (P1A1)

Besides that, students have very poor knowledge of the elements of art. One of them only knew about the line and color in the element of art when asked about the artwork that was produced.

"line, color, hmm. I don't know the others." (T2B2)

"tex...ture is about rough, smooth." (T2B2)

"so hard to explain." (T2B2)

This situation is worrying because of the elements of art is the basis for understanding art. According to teacher $A$, students that understood art are those who have an interest in the subject of the art. This situation ties in with the study by Ariffin (2010) shows that interest is very important for students to learn, especially when related to the creating artwork and art appreciation session. 


\section{No Self Confidence}

Besides that, this study has found that students do not have the confidence to give an opinion when doing art appreciation in class. Through observations, it has been found that students sit quietly and do not dare to answer when asked by the teacher. When an artwork is completed, students are only able to comment on whether an artwork created by their friend is pretty or not, without being able to explain the aesthetic values of the artwork. Students also comment in a low voice. Besides that, students are unsure of their answer and only give comments such as "pretty...like..." when judging their friend's artwork. This is supported during the following observation,

\footnotetext{
"The teacher asked the students for comments, but they kept quiet and only said it's pretty. The students' response was lacking so the teacher asked questions to stimulate their thinking. The students' desire to know the answers were low." (P1A1)

"The teacher asked the students to review what they had learned at the conclusion of the lesson, but the student refused to answer." (P1A1)

"Other students laughed at a friend's unappealing artwork when it was in front of the class. I felt very embarrassed." (P1A1)

"Students are not motivated. When they see it's their turn (to give some art appreciation) they will ask permission to go to the washroom or early recess." (P1A1)
}

The findings of the interviews with the students also showed that students do not have the self-confidence to comment on their friend's artwork.

"The confidence to express in terms element of art is very low especially when it comes to speaking in Malay Language" (T2A2)

"I do answer when the teacher asked, but only a little because I'm scared and I don't know what to comment. I'm afraid the teacher will be sad because the teacher has taught us." (T2B2)

"I seldom. My friends always laugh at me. I don't want to comment but sometimes I answer the teacher's question and state the terms element and principles of art." (T2C2)

Students' confidence to give opinions and feelings are very important in the sharing of ideas during discussions. It reflects their knowledge and ability to interact with their friends and the artwork created. This is in line with a study by Chia (2011) that found the integration of art appreciation can develop students' communication and writing in class. If their communication is ineffective, they will feel afraid and lose confidence to give comments or critiques.

\section{Level of Students' Comprehension during Art Appreciation Session}

Based on the data from the interviews and observations, this study has found that students' comprehension level during art appreciation session is moderate. For example,

"Hmm.... it's alright. I understand the element of art well enough." (T2C2) 
Vol. 8, No. 4, 2019, E-ISSN: 2226-6348 @ 2019 HRMARS

"Sometimes I will review and do my own art appreciation. I don't follow the teacher's way of doing art appreciation." (T2A2)

"It is difficult to teach the students because it is hard to control them and they are less responsive in their attitude when the teacher is teaching. Sometimes all of them keep quiet and only say it's pretty." (P1A1)

The responses given show that students are still unsure when art appreciation session is done. Students do understand the element of art like lines, color, form, shape, space and texture; but they are not fully able to express in terms element of art during an art appreciation session. The importance of integrating art appreciation is still low. This finding corresponds with Setiawan (2007) in that art appreciation is seldom done hence it does not improve students' ability to judge an artwork. The teachers' perception towards the method of teaching this subject is quite uninformed especially with the non-experience of teaching art appreciation. Besides that, students' intrinsic and aesthetic values are very important in developing students' experience (Law, 2010).

This study has also found that students are weak in the usage of art language if they have to explain it in Malay Language. This is because most subjects taught in Chinese vernacular schools are in the mother tongue. Usually, for pupils from Year 3 to Year 5, Malay teachers would teach this subject. With that, pupils face language problems when using Malay Language. This is seen from the interviews of the participants of this study,

"They face problems when doing art appreciation in Malay Language. They are unable to remember the terms and some students do not understand what is asked by the teacher. Furthermore, looking at their attitude, they prefer to mix with their own race. If the student is Chinese, all Chinese friends only. If Malay, then Malays only...they want it that way only...the people they want with them. They do not want to mix with students of other races. So, when students do not mix around, it becomes a problem where they're not able to use Malay Language." (T2A2)

"One more problem that I noticed here is the students' attitude. Some students are really interested and want to try speaking in Malay Language. However, sometimes students still answer the teacher orally in Chinese. They will mix the language and say that...that... (explains the word they try to convey)." (P1A1)

"The picture shown was a bottle. The students were asked to explain the elements and principles of art. Hmm... I know! The answer is balance (Chinese)." (T2C2)

The findings show that students understood the elements and principles of art, but they face problems in using the terms in Malay Language. Students prefer to use Chinese to communicate. This finding is in line with Duh (2016), which shows that a person's mastery of language will improve his or her speech and develop his or her appreciation of art.

This study has shown that students' inability to use art language also comes from the art teacher themselves. This is because the teacher has not majored in art, and they have not been exposed to the skills and knowledge on how to execute art appreciation sessions in class. 


\section{Conclusion and Recommendations}

Teachers play an important role in the realization of art appreciation in the classroom. Students' understanding of doing an art appreciation will produce a generation that is art literate, thus able to experience, understand and appreciate art better. Overall, this study has found that students' understanding and ability to use elements of art during an art appreciation session is at a moderate level. This is because the teachers do not have much knowledge of using elements and principles of art, in addition to them not being majors in art. Moreover, the usage of Malay Language among the students is less emphasized. With that, teachers need to be bilingual when explaining the terms and encourage students to understand Malay Language when doing an art appreciation session.

Hence, teachers should always try to improve themselves by mastering the content for the art subject beforehand, so that the art appreciation session can be executed successfully in class. For example, teachers can apply and attend online courses to improve teaching methods. Teachers can also implement Professional Learning Community (PLC) as a platform to share skills, knowledge and resources around them. With this, the issue of teachers not majoring in art can be discussed and solved immediately. Self-improvement of the teacher's knowledge is the key to the development and creativity growth in children's ideas. Art appreciation sessions not only develop children's skills and understanding, but also shape a positive and balanced character intellectually, socially, physically, emotionally and spiritually, as envisioned in the National Philosophy of Education (FPK) in Malaysia.

\section{Corresponding Author}

Cherise Tan Sheau Ping

Faculty of Education, University of Malaya, 50603 Kuala Lumpur,

Malaysia.

Email: cherisetan92@gmail.com

\section{References}

Ali, Z. (1989). Seni dan seniman: esei-esei seni halus. Kuala Lumpur: Dewan Bahasa dan Pustaka, Kementerian Pendidikan Malaysia.

Ariffin, M. S. N. (2010). Sejauhmana keberkesanan perlaksanaan sesi apresiasi seni di sekolah menengah dalam pendidikan seni. (Masters thesis). Universiti Pendidikan Sultan Idris, Perak.

Carroll, N. (2016). Art appreciation. The Journal of Aesthetic Education, 50, 1-14. doi:10.5406/jaesteduc.50.4.0001

Chia, J. Y. (2011). Cross-cultural understanding through art appreciation: The use of constructivist pedagogy. (Doctor Thesis). University of Georgia, Georgia. Retrieved from http://purl.galileo.usg.edu/uga_etd/chia_ju-yi_201105_edd

Duh, M. (2016). Art Appreciation for Developing Communication Skills among Preschool Children. CEPS Journal, 6, 71-94. 
INTERNATIONAL JOURNAL OF ACADEMIC RESEARCH IN PROGRESSIVE EDUCATION AND DEVELOPMENT

Vol. 8, No. 4, 2019, E-ISSN: 2226-6348 @ 2019 HRMARS

Fagley, N. S. (2012). Appreciation uniquely predicts life satisfaction above demographics, the Big 5 personality factors, and gratitude. Personality and Individual Differences, 53(1), 59-63. doi:10.1016/j.paid.2012.02.019

Hamid, M. J. A. (2004). Falsafah dan kritikan seni. Perak: Penerbit Universiti Pendidikan Sultan Idris.

Hedayat, M., Kahn, S. M., Honarvar, H., Bakar, S. A. S. A., \& Samsuddin, M. E. (2013). The effect of DBAE approach on teaching painting of undergraduate art students. Educational Research and Reviews, 8, 1322-1330. doi:10.5897/ERR2013.1491

Ibrahim, C. M. T. C. (2007). Praktik pengajaran dan persepsi pelajar Sekolah Menengah Mahmud, Raub, Pahang terhadap apresiasi seni. Universiti Pendidikan Sultan Idris,

Ismail, F. (2015). Kemahiran Menvisualisasi Ruang Dalam Kalangan Pelajar Bagi Mata Pelajaran Pendidikan Seni Visual. (Masters thesis). Universiti Tun Hussein Onn Malaysia, Johor.

Khalid, N., Pahi, M. H., \& Ahmed, U. (2016). Loosing your best talent: Can leadership retain employees? The dilemma of the banking sector of Hyderabad Sindh, Pakistan: A mediation investigation. International Review of Management and Marketing, 6(3), 608616.

Kementerian Pendidikan Malaysia. (2017). Kurikulum Standard Sekolah Rendah Semakan 2017. Putrajaya: Kementerian Pendidikan Malaysia

Law, S. S. M. (2010). An Interdisciplinary Approach to Art Appreciation. New Horizons in Education, 58(2).

Leder, H., Belke, B., Oeberst, A., \& Augustin, D. (2004). A model of aesthetic appreciation and aesthetic judgments. British journal of psychology, 95(4), 489-508.

Madrid, D., Ahmed, U., \& Kumar, R. (2019). Examining the Impact of Classroom Environment on Entrepreneurship Education: Case of a Private University in Bahrain. Journal of Entrepreneurship Education, 22(1), 1-8.

Maneen, C. A. (2016). A case study of arts integration practices in developing the 21st century skills of critical thinking, creativity, communication, and collaboration. Gardner-Webb University, Retrieved from https://digitalcommons.gardner-webb.edu/education_etd/182

Meel-Jansen, A. V. (2006). The magical number five in art appreciation. Empirical Studies of the Arts, 24(1), 107-118.

Noaparast, K. B., \& Noaparast, M. Z. B. (2011). Aesthetic formalism, reactions and solutions. Hekmat va Falsafe (Wisdom and Philosophy), 6, 101-112.

Novaković, S. (2015). Preschool teacher's role in the art activities of early and preschool age children. Croatian Journal of Education, 17(0). doi:10.15516/cje.v17i0.1497

Parsons, G. (2004). Moderate formalism as a theory of the aesthetic. Journal of Aesthetic Education, 38(3), 19-35. doi:10.2307/3527441

Savva, A., \& Trimis, E. (2005). Responses of young children to contemporary art exhibits: The role of artistic experiences. International Journal of Education and the Arts, 6.

Setiawan, D. H. (2007). Pembelajaran apresiasi seni rupa di Sekolah Dasar Negeri II Mojorebo Wirosari Grobogan. Universitas Negeri Semarang,

Subramaniam, M. (2017). The development of a tertiary level visual communication module incorporating an art appreciation approach. (PhD thesis). University of Malaya, Kuala Lumpur. 


\section{INTERNATIONAL JOURNAL OF ACADEMIC RESEARCH IN PROGRESSIVE EDUCATION AND}

DEVELOPMENT

Vol. 8, No. 4, 2019, E-ISSN: 2226-6348 C 2019 HRMARS

Tekiner, D. (2006). Formalist art criticism and the politics of meaning. Social Justice, 33(2 (104)), 31-44. Retrieved from http://www.jstor.org/stable/29768369

Terreni, L. (2016). Visual Arts Education for Young Children In Aotearoa New Zealand. Journal Of Childhood Studies, 41. doi:10.18357/jcs.v41i4.16718

Woon, Y. L. (2015). Perbandingan tahap minat, persepsi dan tahap pencapaian akademik di antara murid melayu dan cina tingkatan empat terhadap Pendidikan Seni Visual di Zon Bangsar Kuala Lumpur. Universiti Malaya, Kuala Lumpur. 